\title{
Peripheral blood Th9 cells and eosinophil apoptosis in allergic asthma patients
}

\author{
Deimante Hoppenot ${ }^{*}$, Kestutis Malakauskas, Simona Lavinskiene, leva Bajoriuniene, Virginija Kalinauskaite, \\ Raimundas Sakalauskas
}

From 5th International Symposium on Molecular Allergology (ISMA 2013)

Vienna, Austria. 6-7 December 2013

\section{Background}

Th9 cells are novel identified subset of CD4+ T helper cells, which could contribute to airway inflammation in allergic asthma. The role of Th9 cells and their interaction with eosinophils is still not fully understood. The aim was to evaluate peripheral blood Th9 cells and eosinophil apoptosis in patients with allergic asthma.

\section{Material and Methods}

18 patients with allergic asthma (AA) and 14 patients with allergic rhinitis (AR) were examined. The control group included 16 healthy subjects (HS). All AA and AR patients did not take inhaled corticosteroids at least for one month and/or histamine antagonists at least for one week. Peripheral blood eosinophils and CD4+ cells were isolated by high density gradient centrifugation and magnetic separation. Th9 cells and apoptotic eosinophils were estimated by flow cytometer. Serum interleukin-9 (IL-9) and interleukin-5 (IL-5) level was determined by ELISA.

\section{Results}

Percentage of peripheral blood Th9 cells was increased in AA patients compared with AR patients and HS group $(0.73 \pm 0.32 \%$ vs. $0.51 \pm 0.10 \%, 0.16 \pm 0.08 \%, \mathrm{p}<0.05$, accordingly). The same tendency was observed for serum IL-9 level in all groups $(75.6 \pm 9.1 \mathrm{pg} / \mathrm{ml}$ vs. $50.5 \pm$ $9.7 \mathrm{pg} / \mathrm{ml}, 37.8 \pm 4.7 \mathrm{pg} / \mathrm{ml}, \mathrm{p}<0.05$, accordingly). Percentage of peripheral blood apoptotic eosinophils was decreased in AA and AR patients groups compared with HS group ( $3.42 \pm 1.29 \%, 4.85 \pm 0.97 \%$ vs. $7.83 \pm 1.40 \%$, $\mathrm{p}<0.05$, accordingly). Serum IL-9 level significantly correlated with percentage of Th9 cells $(\mathrm{r}=0.64, \mathrm{p}<0.05)$ and negatively with percentage of apoptotic eosinophils in

\footnotetext{
Lithuanian University of Health Sciences, Department of Pulmonology and
} Immunology, Kaunas, Lithuania

(c) 2014 Hoppenot et al; licensee BioMed Central Ltd. This is an Open Access article distributed under the terms of the Creative Commons Attribution License (http://creativecommons.org/licenses/by/2.0), which permits unrestricted use, distribution, and reproduction in any medium, provided the original work is properly cited. The Creative Commons Public Domain Dedication waiver (http://creativecommons.org/publicdomain/zero/1.0/) applies to the data made available in this article, unless otherwise stated. 